Name

Address

City

FL Zip

Date E-Mail *
Direct any questions regarding this test or the interpretation of the results to your county Extension Agent.

In order to expedite reporting of results; please provide an e-mail address if possible.

NOTE: This service is limited to: (Please check the appropriate box.)

$\square$ Diagnostic samples submitted by UF/IFAS Extension agents or specialists.

$\square$ Commercial Blueberry or Pecan Samples. The fee for blueberry/pecan tissue analysis is $\$ 10.00$ per sample. Make checks payable to University of Florida. Samples cannot be processed without payment.

Fill in all requested information, using one line per sample and additional sheets for more than $\mathbf{5}$ samples.

\begin{tabular}{|l|l|l|l|l|l|}
\hline Lab Use Only & Sample ID & County & Crop & $\begin{array}{l}\text { For Extension Diagnostic Leaf Tissue Analysis, } \\
\text { Provide Client's Name and Address Below: }\end{array}$ & $\begin{array}{l}\text { Name: } \\
\text { Address: }\end{array}$ \\
\hline & & & & $\begin{array}{l}\text { Name: } \\
\text { Address: }\end{array}$ \\
\hline & & & $\begin{array}{l}\text { Name: } \\
\text { Address: }\end{array}$ \\
\hline & & & $\begin{array}{l}\text { Name: } \\
\text { Address: }\end{array}$ \\
\hline
\end{tabular}

For commercial blueberry or pecan samples, indicate payment type:

Check

Money Order

Cash Total

\title{
Important Information
}

- Plant tissue analysis includes: $\mathbf{N}, \mathbf{P}, \mathbf{K}, \mathbf{C a}$, and $\mathbf{M g}$ (in percent); and $\mathbf{B}, \mathbf{C u}, \mathbf{F e}, \mathbf{M n}$, and Zn (in ppm).

- Extension Diagnostic Plant Tissue samples can only be submitted by a Florida Extension agent or specialist. Sample results are provided only to the agent/specialist, who is responsible for data interpretation for the client. This service is offered as a

free educational service in support of the Florida Cooperative Extension Service.

- Blueberry and Pecan samples may be submitted directly by the grower. Sample results are forwarded to an Extension blueberry or pecan specialist who evaluates the data and provides a report to the grower.

\section{How To Take, Prepare, and Submit Plant Tissue Samples for Analysis}

1. Ensure that each sample contains at least a generous handful of plant material.

2. Do not sample leaves contaminated with soil or sprays. If all tissue is dusty or spray contaminated, wash leaves gently with flowing distilled water.

3. Do not sample disease-, insect-, or mechanically damaged plant tissue.

4. Place tissue samples directly into a clean paper or cloth bag or envelope. Do not use plastic containers. If the plant tissue is wet or succulent, allow plant material to air dry for at least one day, before mailing.

5. Make checks payable to University of Florida
6. When sampling suspected nutrient-deficient plants, two samples are recommended; one sample from normal plants, and another sample from abnormal plants.

7. When sampling, the plant part and plant maturity are important factors. Be sure to collect the proper plant part at the recommended time. A general rule of thumb is to sample the youngest, fully mature leaves during the growth cycle, or just prior to fruit set.

8. Mail this information sheet, your sample(s), and payment (if applicable) to: IFAS Analytical Services Laboratories, Extension Soil Testing Laboratory, PO Box 110740 / Wallace Building 631, Gainesville, Florida 32611-0740. 